\title{
Muscle proportionality: The proportionality of skeletal muscle before and after intervention
}

\author{
Brian A Jones ${ }^{1 *}$, Robert T Davidson ${ }^{2}$ \\ From The Twelfth International Society of Sports Nutrition (ISSN) Conference and Expo \\ Austin, TX, USA. 11-13 June 2015
}

\section{Background}

There are many types of intervention that can lead to a change in lean body mass including: hormone replacement therapy, aging, menopause, strength training, aerobic exercise, extreme weight loss interventions (gastric bypass surgery), and starvation. Lean body mass is a metabolically active tissue which is involved in several key functions in the body, including: locomotion, basal metabolic rate, and strength. The purpose of this study was to assess the proportionality of changes of regional lean body mass (arms, trunk and legs) before and after intervention.

\section{Methods}

A systematic search was conducted utilizing these key phrases, "muscle proportionality", "regional muscle proportionality", and "DXA regional muscle studies". Also, each study had to fit within the search criteria which included; DXA regional lean body mass before and after intervention randomized controlled studies. After the preliminary search was conducted, a total of 10 studies fit the search criteria for this study. Initial versus final regional lean body mass was plotted and linear regression $\mathrm{R}^{2}$ for total as well as, regional lean body mass (LBM) changes was determined.

\section{Results}

Muscle proportionality was linearly correlated in three specific regions of the body including: arms $\left(\mathrm{r}^{2}=0.94\right.$, $\mathrm{p}<0.0001)$, legs $\left(\mathrm{r}^{2}=0.97, \mathrm{p}<0.0001\right)$, and trunk $\left(\mathrm{r}^{2}=\right.$ $0.89, \mathrm{p}<0.0001)$. Total body muscle proportionality was also linearly correlated $\left(r^{2}=0.99, p<0.0001\right)$.

\footnotetext{
* Correspondence: whobjones@hotmail.com

'Health and Sport Sciences Division, Missouri Baptist University, St. Louis, MO, 63141, USA

Full list of author information is available at the end of the article
}

\section{Conclusion}

In studies utilizing no or whole body weight training, muscle change - gain or loss - appears to occur proportionately to where it was before the intervention. This data could prove beneficial for healthcare professionals when designing nutrition protocols and assessing lean body mass change over time.

\section{Authors' details}

${ }^{1}$ Health and Sport Sciences Division, Missouri Baptist University, St. Louis, MO, 63141, USA. ${ }^{2}$ Nutrition and Human Performance, Logan University, Chesterfield, MO, 63017, USA.

Published: 21 September 2015

\section{doi:10.1186/1550-2783-12-S1-P51}

Cite this article as: Jones and Davidson: Muscle proportionality: The proportionality of skeletal muscle before and after intervention. Journal of the International Society of Sports Nutrition 2015 12(Suppl 1):P51.

\section{Submit your next manuscript to BioMed Central and take full advantage of: \\ - Convenient online submission \\ - Thorough peer review \\ - No space constraints or color figure charges \\ - Immediate publication on acceptance \\ - Inclusion in PubMed, CAS, Scopus and Google Scholar \\ - Research which is freely available for redistribution \\ Submit your manuscript at www.biomedcentral.com/submit}

